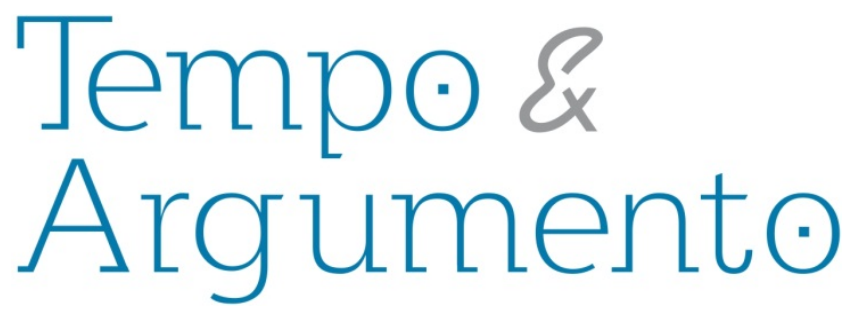

\title{
Mapas do corpo: fotografia, ciência e sensorialidade
}

\begin{abstract}
Resumo
O presente artigo tem como foco discutir os usos da fotografia a partir de dois trabalhos apresentados no Congresso da Língua Nacional Cantada de 1937, por Edgar Roquette-Pinto e João Lellis Cardoso. O Congresso, organizado por Mário de Andrade, tinha o objetivo definir e traçar estratégias para sistematizar as pronúncias do português brasileiro. As apresentações em questão propunham o uso da "fonofotografia" - ou fotografia do som - como ferramenta para decodificar e corrigir as "imperfeições" da língua falada/cantada em diversas regiões do país. Com base nas experiências do físico norte-americano Dayton Clarence Miller e do psicólogo Carl Seashore, tais trabalhos representavam, mesmo que de forma ingênua, a ânsia em dominar os instintos, passíveis de serem acessados pela via sonora, através do campo visual.
\end{abstract}

Palavras-chave: Fotografia; Som; Congresso da Língua Nacional Cantada; Sensorialidade.

\section{Marcelo Róbson Téo}

Doutor em História Social pela Universidade de São Paulo (USP). Pesquisador colaborador junto ao departamento de História da Universidade de Campinas (UNICAMP). Brasil marceloteo@hotmail.com

\section{Para citar este artigo:}

TÉO, Marcelo. Mapas do corpo: fotografia, ciência e sensorialidade. Revista Tempo e Argumento,

Florianópolis, v. 8, n. 17, p. 29 - 63. jan./abr. 2016. 


\title{
Body maps: photography, science, and sensoriality
}

\begin{abstract}
This article focuses on discussing the uses of photography through two papers presented at the 1937 Congress of the Brazilian National Sung Language, by Edgar Roquette-Pinto and João Lellis Cardoso. The Congress, organized by Mário de Andrade, aimed to define and devise strategies to systematize pronunciations in the Brazilian Portuguese language. These presentations proposed using 'phonophotography' - or 'sound picture' - as a tool to decode and correct the 'flaws' of spoken/sung language in various regions in the country. Based on the experiences of the U.S. physicist Dayton Clarence Miller and the psychologist Carl Seashore, such papers represented, even naively, the eagerness to master instincts, which may be accessed via sound, through the visual field.
\end{abstract}

Keywords: Photography; Sound; Congress Of The Brazilian National Sung Language; Sensoriality.

\section{Cultura das imagens}

À exceção da imagem e do som, passíveis de serem captados, não podemos transportar no tempo ou no espaço fragmentos do mundo percebido por outros sentidos, pois não há forma de registro possível para o tato, o paladar e o olfato. No caso do som gravado e do instantâneo fotográfico, são estabelecidas relações bastante diferentes no que diz respeito às funções e ao seu vínculo com o real. Basta lembrarmos como no cotidiano raramente concedemos à gravação o status de testemunho ou documento, pois nem sempre reproduz a perspectiva de quem ouve (e grava). Gravamos sons interessantes, lembretes, palestras e conversas que contenham informações úteis, ideias, timbres de voz de pessoas queridas, canções, ou seja, vestígios imateriais de nossa existência. Salvo raras exceções (como por exemplo gravar de forma premeditada uma conversa que possa incriminar uma pessoa), não usamos tais gravações como prova. Já o 
uso corriqueiro da fotografia funciona, na maioria das vezes, como evidência daquilo que queremos lembrar e que fazemos questão de mostrar termos vivido. É através dos vestígios visuais, preponderantemente, que construímos nossas narrativas acerca do lugar que ocupamos (ou pretendemos ocupar) no mundo.

A que se deve essa confiança excessiva no que pode ser visto em detrimento do que pode ser ouvido/sentido? Tal privilégio do visual não se dá apenas pelo potencial narrativo da imagem, pois, embora menos explorado ou menos percebido enquanto tal, o som é um elemento poderoso na construção narrativa. Há séculos esta pergunta, formulada a partir de pontos de vista diversos, tem despertado a atenção de filósofos, intelectuais e cientistas do ocidente, alegorizando o embate entre razão e instintos através da oposição entre a objetividade do visual e a subjetividade da percepção pelos outros sentidos. Ainda que não tenhamos uma resposta breve e sintética para tal questão, ela nos fornece indícios preciosos acerca das hierarquias sensoriais construídas na longa duração e no seio da cultura ocidental. A associação do ato de ver com a prova racional ou científica, e do ouvir/sentir com o caráter fundamentalmente ambíguo e plural da percepção, é uma construção que antecede em séculos o nascimento da fotografia e que constitui, creio, uma das características centrais do ocidente: o rompimento com o ritual e o esquadrinhamento da realidade através da ciência e do ideal de civilização. A escrita e a imagem, nesse contexto, desempenharam papéis fundamentais.

\section{Culturas do som}

1. Para os aborígenes australianos, é a via sonora que guia as práticas de lembrança e ordenamento do mundo. As relações diplomáticas entre diferentes etnias, as narrativas sobre o passado, a atribuição de funções sociais: estas são algumas das funções atreladas às songlines. ${ }^{1}$ Estas contam de forma dinâmica sobre o passado, atribuindo sentido à paisagem e às ações de deuses e homens no processo de construção do mundo. É através

\footnotetext{
${ }^{1}$ As songlines ou dreaming tracks são cantos aborígenes que demarcam as rotas estabelecidas por deuses e entidades e que auxiliam no deslocamento e exploração dos territórios. O canto é um instrumento de conhecimento, mapeamento, diálogo e preservação do mundo. Tudo passa pela matriz sonora: da reprodução à identificação do mundo, dos seres e das coisas; das aptidões de liderança às relações humanas e intercomunitárias. Para maiores informações, ver CHATWIN, 1996.
} 
das canções que se registra o estado dos monumentos originais (a natureza em si) para que sejam preservados pelo homem. ${ }^{2}$ Sua transmissão sempre teve por base a oralidade e o direito à transformação em acordo com as dinâmicas da cultura e do mundo natural.

2. Na Europa, pintores românticos e, logo adiante, modernistas, apostaram na potência sensorial - não-narrativa - do som e da música para criar imagens que, justamente, fugissem da relação indicial com a realidade. O pintor Wassily Kandinsky, entre muitos outros, investigou inúmeras possibilidades para uma apreciação visual pautada por critérios da escuta (ARNALDO, 2003), de modo que rompesse com a objetividade e a narratividade da pintura pautada pela mimesis. Buscava, então, dar um caráter sensorial ao sentido da visão, como se até então ele atuasse isolado em outra dimensão.

3. No Brasil, modernistas formularam um projeto identitário para o país pautado pela via sonora. Consistia na elaboração de sínteses artístico-intelectuais inspiradas por canções, gestos, danças e sotaques da cultura popular. Nesta última, marcada pela presença africana, indígena e europeia arcaica, residiria o substrato, a essência interior e original da identidade brasileira. Para que esta matéria-prima tomasse forma, entretanto, era preciso que passasse pelo crivo da visualidade, através da pintura, de ensaios literários e escritos intelectuais (TÉO, 2012).

$$
* * *
$$

Desses exemplos, é importante que retenhamos três informações centrais. A primeira, mais óbvia, é a consciência de que a ênfase na visualidade é uma característica da civilização ocidental, e que existem inúmeras formas de articular e hierarquizar os sentidos em outras culturas. A segunda diz respeito à busca, dentro da estética (via filosofia e movimentos artísticos), desde o romantismo, de alternativas à objetividade através da aproximação com o campo musical e sonoro de forma geral. A terceira aponta para os limites dessa alternativa à objetividade, chamando a atenção para a dimensão política da aproximação entre a via sonora e o campo visual.

\footnotetext{
${ }^{2} \mathrm{Na}$ cultura aborígine, o ser humano deve ser essencialmente um protetor do mundo natural, alterando-o o mínimo possível e colaborando para o seu funcionamento. A caça e a coleta, em detrimento da agricultura, são, portanto, parte de um complexo sistema político-social pautado pela preservação e manutenção da natureza.
} 


\section{Cartografia dos sentidos}

A dimensão sonora foi não apenas material privilegiado na elaboração de narrativas alegóricas - literárias ou visuais - do Brasil. Serviu também como instrumento auxiliar na busca pela ordem nacional. A partir dos anos de 1930, temas como a presença maciça de imigrantes (sobretudo no sul do Brasil), o perigo de enquistamento étnico, a disseminação de contraculturas através da música popular urbana ${ }^{3}$ passaram a integrar os debates sobre cultura no país. Nesse cenário, o canto coral, a língua falada e a musicalidade se tornaram temas centrais em meio às discussões e projetos sobre a identidade brasileira. A educação pelo ouvido tornou-se - sobretudo a partir dos anos 30, quando a radiodifusão já alcançava os mais longínquos territórios - uma questão saliente (TÉO, 2007). De um lado a popularidade do cinema a despejar modelos visuais de moda e comportamento (CHARNEY, SCHWARTZ, 2004). De outro, a música popular e as radionovelas povoando o imaginário dos ouvintes com a curiosidade visual despertada pelo enigma das vozes anônimas (CALABRE, 2004). Tanto o cinema quanto o rádio foram utilizados por órgãos estatais e privados como meios de controle e divulgação política, articulando as dimensões visual e sonora em busca de despertar a atenção do público.

A ruidosa modernidade urbana passava a exigir mais dos sentidos, em especial do ouvido, confundido por uma infinidade de estímulos. Criavam-se, assim, novos desafios aos organismos estatais acostumados a empreender ações visuais de diálogo ou de controle voltadas às massas. Meios como a revista inglesa The Listener, fundada em 1929 pelo $1^{\circ}$ diretor geral do grupo BBC, Lord Reith, eram criados para oferecer um contraponto mais intelectualizado ao caráter popularesco das programações radiofônicas. O sugestivo título do semanário é indicativo da atenção que o sentido da audição - e o próprio sujeito que ouve - passava a receber. Necessitava ser educado, pois através dele o efeito da modernidade poderia ser regulado. Os ouvintes (listeners) ideais seriam aqueles que, capazes de superar o caráter raso da cultura de massas, soubessem ou se dispusessem a aprender a - selecionar os conteúdos adequados.

\footnotetext{
${ }^{3}$ Sobre o tema da censura musical no Estado Novo, ver PARANHOS, 2002.
} 


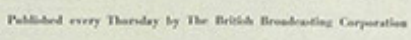

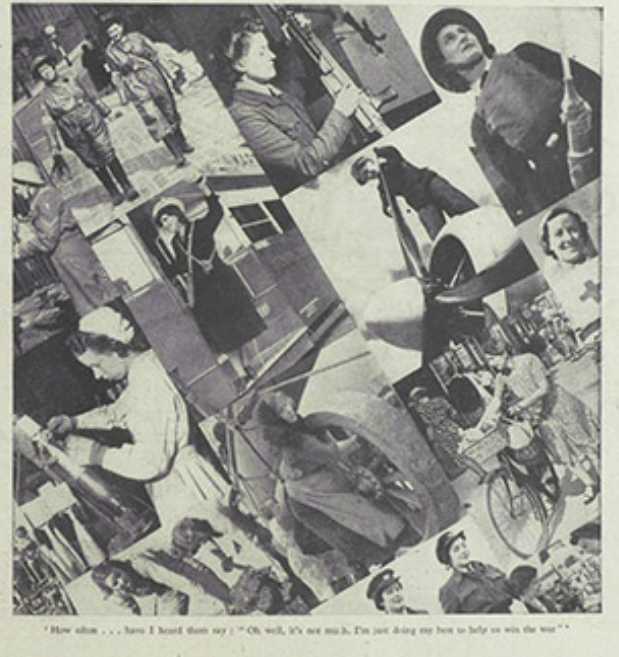

H.M. The Queen's Message to the Women of the Empire
Capa da revista The Listener, 11/4/43.

"HM The Queen's message to the women of the empire: the Queen broadcasts to the women of the empire 'I am proud of you' on 11 April 1943". The Listener Historical Archive, 1929-1991.

No Brasil, tais questões tomavam um rumo muito específico, tendo em vista a preponderância do universo sonoro/musical nas tentativas de definição da cultura popular. Na produção intelectual, o sentido da audição foi extremamente representativo na abordagem do universo sensorial enquanto motivo identitário. Na produção visual, pictórica e ilustrativa, a música funcionou como conector entre o moderno e o nacional. Artistas e intelectuais buscaram na referência sonora o material para esboçar uma imagem definida do Brasil. ${ }^{4}$ Tal tarefa foi levada a sério, tornando-se uma constante na produção posterior à proclamação da República, muito especialmente a partir dos anos 20, com o Modernismo.

O processo de institucionalização do Modernismo, que aos poucos parece assumirse como um moderno nacionalismo de forte apelo político, não deixa de levar em conta

\footnotetext{
${ }^{4}$ Exploro alguns casos em minha tese de doutorado (TÉO, 2012), dentre os quais se destacam a crítica de arte de Mário de Andrade, Gilberto Freyre, especialmente em Casa Grande e Senzala, Graça Aranha (Viagem maravilhosa e Estética da vida), além dos pintores Cândido Portinari, Emiliano Di Cavalcanti, Flávio de Carvalho e José Ferraz de Almeida Júnior. Todos eles desenvolvem diálogos intensos com o campo sonoro. Embora bastante distintos entre si, indicam a recorrência e a relevância destes cruzamentos nas práticas político-culturais de então.
} 
esse apelo sensorial - e muito especialmente auditivo - das formulações artísticointelectuais acerca da identidade cultural brasileira. Pelo contrário: aprofunda o vínculo, levando-o, em algumas situações, ao paradoxal engajamento com a ciência, em busca de racionalizar uma dimensão da cultura que, inicialmente, se opunha a tal processo. Dentre as várias ações do Departamento de Cultura de São Paulo e de sua Divisão de Expansão Cultural, pode-se destacar a fundação de um grupo coral - o Coral Paulistano -, da Discoteca Pública e do Laboratório de Fonética, coordenados pela aluna de Mário de Andrade, Oneyda Alvarenga. Além de formar comissões como a Missão de Pesquisas Folclóricas e a Sociedade de Etnografia e Folclore, a Divisão também promoveu diversos eventos culturais e científicos. Atividades educacionais foram desenvolvidas junto a parques infantis e locais voltados à diversão pública, com uma clara intenção de "moldar os filhos dos proletários (migrantes e imigrantes) de acordo com o controle dos poderes públicos para a constituição de uma sociedade moderna e civilizada" (NOGUEIRA, 2005, p.184). Estas ações tinham por fito, muitas vezes, coibir atividades consideradas inconvenientes e incentivar aquelas que ajudassem a construir o ideal "ilustrado" da nação (PEREIRA, 2006, p. 110).

A adesão a tal modelo ajudava a firmar o ideal paulista para um Brasil moderno, bem como a construir uma imagem promissora do país junto ao cenário internacional. Para tais tarefas, em 1937 o Departamento de Cultura enviou representantes a diversos congressos, dentro e fora do país, dedicados a expor essa versão paulista da cultura brasileira. ${ }^{5}$ Neste mesmo ano, Mário de Andrade organizou o primeiro Congresso da Língua Nacional Cantada, ocorrido entre 7 e 14 de julho, menos de quatro meses antes do golpe que dá início ao regime estadonovista. ${ }^{6} \mathrm{O}$ desejo de educar e sistematizar as pronúncias em prol da uniformização do canto brasileiro foi debatido durante os oito dias do congresso, que ocorreu no Teatro Municipal de São Paulo, praticamente 15 anos após

\footnotetext{
${ }^{5}$ Camargo Guarnieri esteve no II Congresso Afro-Brasileiro na Bahia, que teve em Gilberto Freyre um de seus idealizadores; Sérgio Milliet esteve presente no Congresso da População; e Nicanor Miranda no Congresso Internacional de Folclore, ambos em Paris. Este último apresentou pesquisas da Sociedade de Etnografia e Folclore desenvolvidas especialmente para o evento (BATISTA, 2004, p. 48). Milliet expôs a comunicação São Paulo au microscope, na qual constava uma análise estatística da cidade, por quarteirão, estudando a distribuição de crianças, migrantes, estrangeiros (PEREIRA, 2006, p.111).

${ }^{6}$ Ainda que inicialmente a relação de Mário com o novo regime seja reticente, o evento por ele organizado antecipa - e de certa forma instrumentaliza - algumas questões que serão abordadas pelo governo Vargas ao longo dos anos que seguem.
} 
a Semana de Arte Moderna. E algumas das pesquisas e propostas apresentadas deixam clara a relevância da visualidade como possível campo de tradução e ordenamento da via sonora, fosse ela musical, linguística ou gestual. ${ }^{7}$

A publicação dos anais do Congresso indica a preocupação com a catalogação visual da produção sensorial tida como tipicamente brasileira, sobretudo musical e culinária. É preparada e publicada uma série de "mapas de folclore”, em que constam as manifestações musicais e alimentares das regiões do Estado de São Paulo, organizada pela Sociedade de Etnografia e Folclore e bancadas pelo Departamento de Cultura, sob a chancela de Mário de Andrade. ${ }^{8}$ Foi organizada também pelo Departamento de Cultura a Exposição de Iconografia Musical Brasileira, com mais de dois mil documentos apresentados por instituições públicas e colecionadores do Rio de Janeiro e de São Paulo. ${ }^{9} \mathrm{O}$ registro dessa exposição é incompleto, e pode-se supor que o próprio Mário tenha exposto um número significativo de objetos de sua coleção. ${ }^{10}$

Entre os eventos de caráter artístico, destacou-se a apresentação do Coral Paulistano. Fundado em 1935, o coral, ligado ao Teatro Municipal e ao Departamento de Cultura, contava com um corpo estável de cantores eruditos, os quais foram selecionados criteriosamente entre os meses de setembro e dezembro daquele ano. Camargo Guarnieri foi nomeado regente. O conjunto vocal estreou em março de 1936, realizando diversas apresentações, sempre voltadas para a divulgação da música brasileira,

7 Serão abordadas aqui apenas as informações acerca do Congresso pertinentes à problemática deste trabalho. Para uma abordagem mais geral sobre o evento, ver SERPA, 2000 e PEREIRA, 2006.

${ }^{8}$ Entre os mapas publicados nos Anais do Congresso (1938), estão: Mapa de Danças populares: congada e suas variantes fonéticas (variações no nome - congada, congado, congo); Mapa de Danças populares: caiapó e suas variantes fonéticas (variações no nome - caiapó, caiapós, caiapô); Mapa de Danças populares: cururu ou caruru; Mapa de Danças populares: samba ou batuque; Mapa de Danças populares: cateretê ou catira; Mapa de Proibições alimentares: relativas à manga; Mapa de Proibições alimentares: leite com frutas; Mapa de Medicina popular: cura do terçol com anel; Mapa de Zona estudada; Mapa das unidades territoriais.

${ }^{9}$ Cf. Anais do I Congresso da Língua Nacional Cantada, 1938, p. 4.

${ }^{10}$ Tratados musicais integraram a mostra, tais como edições antigas de obras de Gioseffe Zarlino (1517-90), teórico musical italiano que, além dos escritos sobre contraponto e afinação, também explorou as relações entre cor e som; obras do compositor e teórico Jean-Philippe Rameau (1683-1764) e de seu rival Jean-Jacques Rousseau; edições antigas de Jean de Léry contendo músicas indígenas, além de partituras como a de Petite Sérénade, op. 50, composta pelo Visconde de Taunay sob o Pseudônimo de Flavio Elysio, e que teria sido o primeiro esboço da composição que mais tarde foi impressa com o título de Souvenir de Petropolis. Também foram expostas obras iconográficas que registraram, ao longo da história do país, momentos musicais, como a Serenata em São Paulo no Primeiro Império (desenho, $22 \mathrm{x}$ $17 \mathrm{~cm}$ ), e a Congada (cortejo dos reis do Congo) (guache, $34 \times 50 \mathrm{~cm}$ ), ambas de Johann Moritz Rugendas. 
restringindo-se à apresentação de peças em português, latim ou traduções (PEREIRA, 2006, p. 109-10). ${ }^{11}$ O grupo vocal desenvolvia ainda pesquisas em busca de um timbre nacional, ideal este que se confundia com o objetivo do evento.

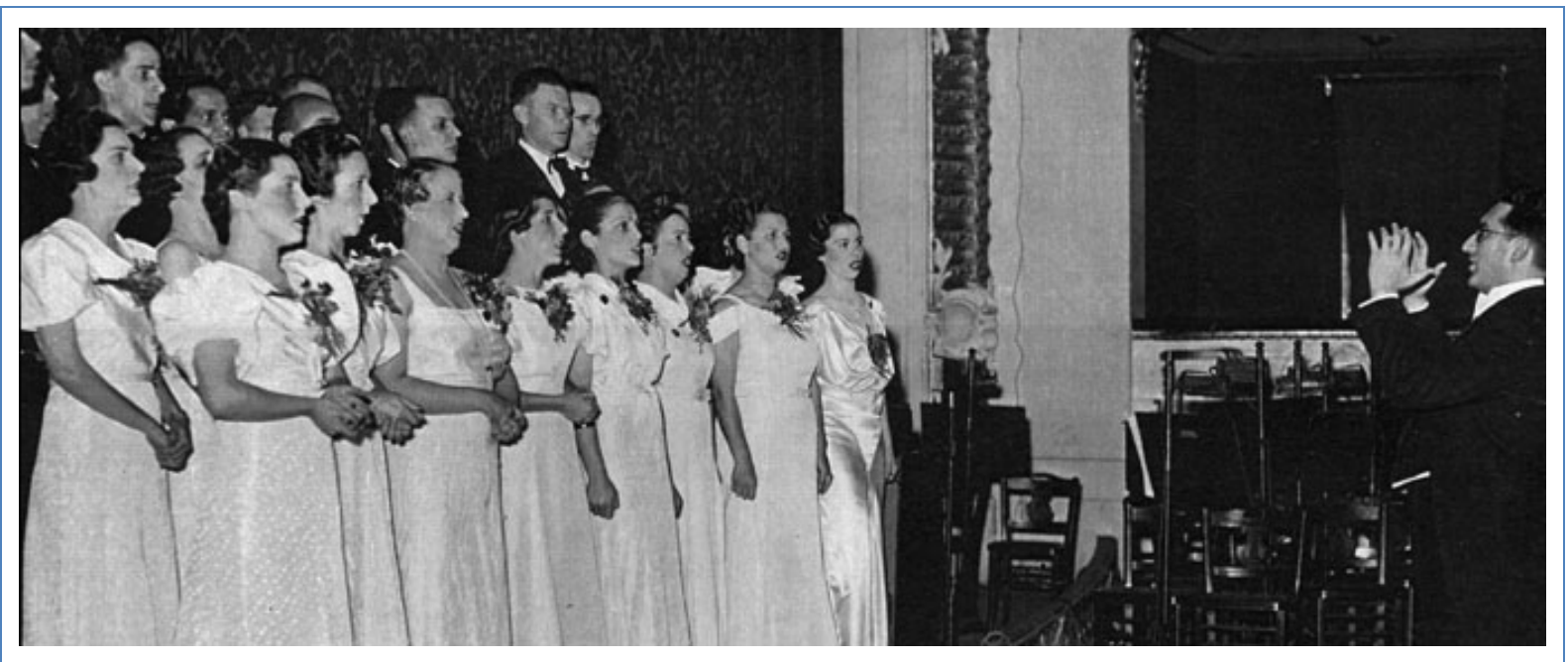

Camargo Guarnieri à frente do Coral Paulistano, função que exerceu entre os anos de 1936 e 1938. Acervo Mário de Andrade. Instituto de Estudos Brasileiros (IEB-USP).

No discurso de abertura, Mário dá as boas-vindas salientando o caráter avesso às tensões políticas do momento, reduzindo seu alcance ao âmbito do "saber e da arte".

Não sei, meus Senhores, si estais bem conscientes da insensatez maravilhosa da nossa decisão de nos reunirmos neste Congresso da Língua Nacional Cantada. Enquanto a política rosna lá fora, fundando imperialismos absurdos, nacionalismos estufados e mil e uma facetas, por onde se odiarem os homens; através dos espaços arejados os congressos se correspondem na insensatez aparente da paz, do saber e da arte. É o Congresso Internacional de Folclore de Paris; é o Congresso das Cidades e Poderes organizado por Bruxelas, é o Congresso da Expansão Portuguesa no Mundo, em Lisboa. E é o Congresso da Língua Nacional Cantada, o primeiro congresso musical do Brasil, que neste momento abre a sua semana de pesquisas e de arte, nesta, de todos vós, cidade de São Paulo ( CONGRESSO, 1938, p. 707).

As primeiras palavras proferidas pelo organizador do evento aos convidados vindos de fora são, portanto, de paz, acolhendo intelectuais e artistas de todo o país na

\footnotetext{
${ }^{11}$ Para maiores informações, ver também SILVA, 2001.
} 
cidade de São Paulo, anunciada como uma espécie de capital da cultura nacional. Todavia, reduzir a significação do Congresso ao universo do canto, da performance e da língua em suas dimensões estéticas seria ignorar algumas de suas implicações mais fundamentais. $O$ Congresso realizava-se como parte de um projeto político que tinha no Departamento de Cultura o seu carro-chefe. Vale atentar especialmente para o valor atribuído aos encontros científico-culturais que então proliferavam. Tais eventos eram realizados em torno de temáticas culturais, sempre ligadas ao universo da ciência, conexão reveladora da tendência intervencionista que caracterizou a ação estatal naquele momento, tanto na América Latina quanto na Europa. Em outro trecho do discurso, Mário argumenta:

Quando Bartolomeu de Gusmão voou pela primeira vez, quando Oswaldo Cruz saneou o Rio de Janeiro, quando Euclides da Cunha descreveu "Os Sertões" ou Carlos Gomes a "Fosca", nenhum sangue correu nem os homens se odiaram mais. E si acaso, nos perfeitos momentos de humanidade vamos em busca do Brasil e sua verdadeira significação histórica no mundo, jamais o encontraremos na Guerra do Paraguai ou 1889, mas em Gusmão, no Butantã, em Castro Alves ou na São Francisco de São João d'El Rei (CONGRESSO , 1938, p. 708).

Essa concepção da história se afina, em parte, com o ideal de "história profunda" firmado após a proclamação da República pela geração de Sílvio Romero. ${ }^{12}$ Contudo, ao deslocamento aparente do campo político para o campo da cultura proposto por Romero em sua História da literatura brasileira, é acrescida a dimensão da ciência, agora equiparada e associada à produção cultural e artística. Mário pretendia, assim, inserir o Congresso no rol de eventos fundadores do Brasil moderno. Para isso, convidou não só artistas, críticos e intelectuais, mas homens de ciência que, de alguma forma, estabelecessem o elo entre os campos da cultura e da pesquisa científica. E a ideia da

\footnotetext{
${ }^{12} \mathrm{O}$ ideal de história profunda defendido pela geração de Sílvio Romero se opunha à história heroica e factual do IHGB. Num cenário de afirmação republicana, valiam-se da cultura popular como fonte privilegiada para o desvendamento da identidade nacional. $O$ estudo das manifestações sonoras entre as populações mestiças representava, então, o erguimento de uma história nacional, pois ao seu conhecimento associava-se a edificação de um temperamento brasileiro, como mostram os estudos de Romero sobre a poesia e a canção popular. A pureza do nacional viria da mistura racial (ROMERO, 1977, p. 38), cujo locus principal seria a canção popular rural, fruto da invenção poética "natural" - porque inculta - e do gesto criativo. O material popular torna-se motivo para uma história profunda, pautada num ideal republicano de aproximação entre povo e Estado. Esse interesse pelo popular é eminentemente etnográfico, e não estético, como virá a ser a partir da década de 1920. Ver TURIN, 2009.
} 
música como conector entre o passado colonial e o presente moderno é reafirmada com a organização do evento.

O convite feito a Cândido Portinari para a ilustração da capa da programação é significativo, tanto pela pretensão de dar status ao evento, quanto pela associação implícita - mas bem compreendida pelo pintor - entre a fundação do país e a imagem do Brasil moderno através da alegoria da aula de música. Na carta enviada ao pintor em 30 de abril de 1937, Mário argumenta:

Em que um pintor pode contar no Congresso? Cristo: o Congresso vai dar vários concertos na semana dele, pelo menos três. Ora, os programas devem ter capa, uma capa única, que quero firmada pelo maior pintor e maior desenhista do Brasil: você. O tamanho da capa é o que vai junto. Você faça o que quiser: desenho em branco e preto, desenho em colorido, aquarela, guache, o que quiser. Nessa capa devem estar os seguintes dizeres: Teatro Municipal (sem h) e Congresso da Língua Nacional Cantada. E além disso, o desenho que você quiser, alusivo a cantar, corais, cantadores populares, o que você quiser desse gênero (ANDRADE, 1995, p. 56-7).

O pedido é sorrateiramente objetivo, delimitando um campo temático bem específico, restrito a três elementos, todos considerados na versão final do pintor: o ato de cantar, a organização coral e a presença popular. O coro de mulatas realizado por Portinari passa bem a intenção educadora e homogeneizante por detrás da pesquisa acerca da língua cantada. O tema da aula de música assumia um duplo papel na constituição da identidade nacional: histórico, ao receber a chancela de momento fundador da civilização tropical com as aulas de música professadas pelos jesuítas nas missões coloniais; e modernizante, ao sancionar uma nova fase da República pautada pelo ordenamento da riqueza cultural do país através de uma relação profunda entre a estética e a ciência (TÉO, 2015). Tornar efetivo e sólido esse elo sonoro entre o passado colonial e o Brasil moderno, portanto, pode ser considerado um dos objetivos centrais do evento, o qual se inseria dentro de um processo mais amplo de escolha, fixação e ordenamento da identidade cultural e artística do país. 


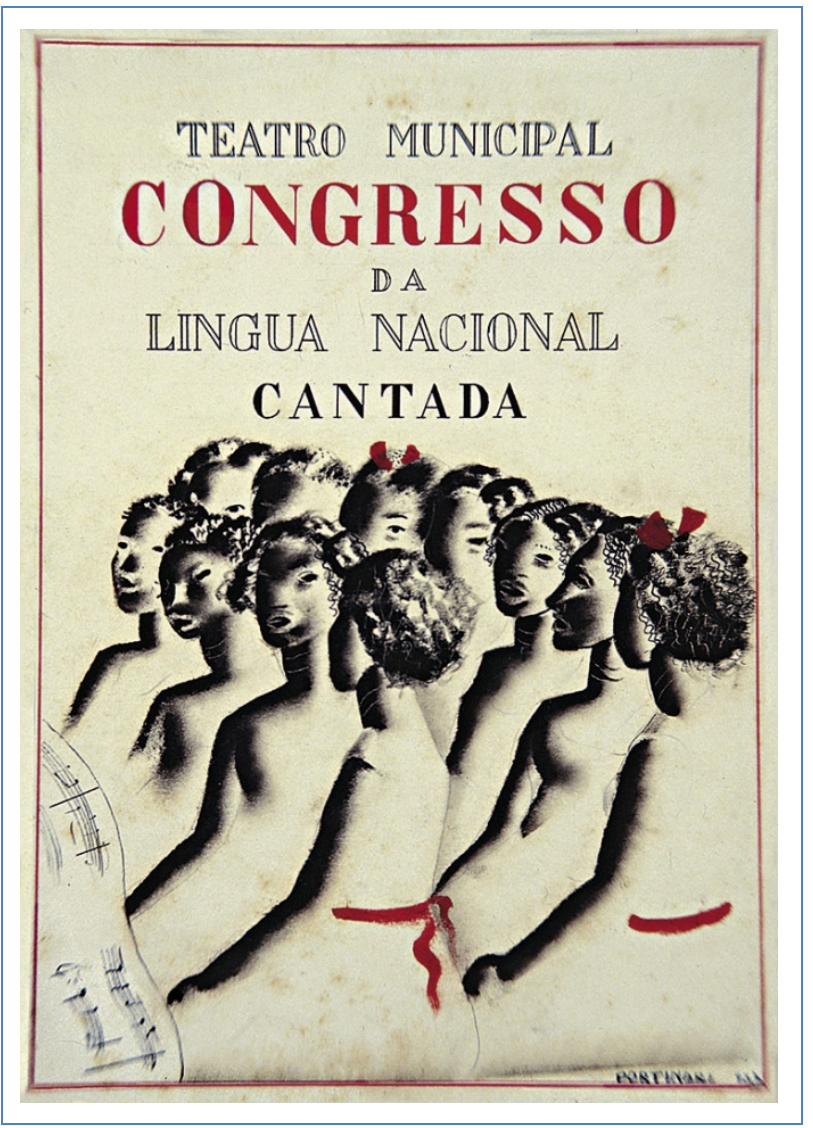

Cândido Portinari. Coro de mulatas (capa dos Anais do Congresso da Língua Nacional Cantada), 1937. Desenho a guache, nanquim bico-de-pena e nanquim pincel/papel $(23.2 \times 16.2 \mathrm{~cm}$ (I) $25.6 \mathrm{x}$ $18.4 \mathrm{~cm}(\mathrm{~S})$ (aproximadas). Instituto de Estudos Brasileiros da USP, Coleção Mário de Andrade, São Paulo.

O Congresso reuniu estudiosos da língua nacional, especialmente foneticistas, atores teatrais, cantores, professores de canto, musicistas e artistas em geral, jornalistas, cientistas sociais, técnicos ligados a diversas áreas, os quais apresentaram trabalhos, debateram e registraram na imprensa nacional. Entre as comunicações apresentadas estavam estudos que iam de tentativas de caracterizar as especificidades do português falado no Brasil até estudos técnicos voltados exclusivamente a oferecer ferramentas científicas capazes de auxiliar no processo de unificação dos acentos ao longo do território nacional. Um número grande de comunicações encampou as problemáticas da língua, da música e da sensorialidade de forma geral. Chamaram atenção duas delas especialmente, que propunham, de maneira relativamente original, um interessante diálogo entre a fotografia/filme e o universo sonoro. Ofereciam, de certo modo, uma fórmula para pôr em prática a cartografia dos sentidos proposta no evento. Vejamos alguns de seus desdobramentos. 


\section{Ver o som, educar os corpos}

Os textos a que me refiro foram apresentados por João Lellis Cardoso e por Edgar Roquette-Pinto. Ambos os casos trazem resultados de pesquisas voltadas à tradução da dimensão sonora para a visual através da fotografia e do filme, estes últimos entendidos não como ferramentas de expressão, mas como partes de um aparato científico necessário ao controle do caos urbano.

1. Sobre o primeiro, João Lellis Cardoso, sabe-se muito pouco. Foi professor do Conservatório Dramático e Musical de São Paulo durante os anos de 1930. Bacharelou-se em Ciências Políticas e Sociais, ministrando cursos na área de Antropologia junto à Escola de Sociologia e Política de São Paulo, com ênfase em temáticas referentes à linguagem. Também prestou assessoria ao IDORT, o Instituto de Organização Racional do Trabalho. ${ }^{13}$ Para a revista deste órgão, escreveu diversos artigos voltados para a psicologia da música e seus papéis na racionalização do cotidiano, sobretudo no contexto operário. ${ }^{14}$

A Revista do IDORT foi fundada em 1932. Com publicação mensal, o periódico teve como colaboradores intelectuais e técnicos de diversas áreas - música, engenharia, saúde, ciências sociais, psicologia, com grande ênfase em estudos psicotécnicos -, de autores nacionais e internacionais. Os temas abordados eram diversos, mas com uma ênfase muito clara sobre a racionalização dos sentidos, ou seja, formas de otimização produtiva do corpo através do controle racional dos estímulos externos e do espaço. Num de seus primeiros números, consta um texto não assinado tratando da importância da música na obtenção de um melhor aproveitamento das atenções no trabalho fabril. 0 pequeno escrito, que tem por base um artigo publicado na revista inglesa Business em

\footnotetext{
${ }^{13}$ A partir das marcas deixadas pela crise de 1929 na economia nacional, e paulista mais especificamente, foram diagnosticadas uma série de fragilidades na estrutura econômica brasileira, então associadas à má organização e à falta de controle eficiente da produção. O IDORT, fundado em junho de 1931 em São Paulo, vinha a suprir essa nova demanda de otimização produtiva através de técnicas racionais de organização e disciplina, seguindo a febre racionalista que vigorava desde a década de 1910. Em suma, era uma "sociedade de estudos e de ação", voltada ao "melhor aproveitamento de todo esforço humano empregado em qualquer das múltiplas manifestações da atividade moderna”, não apenas na indústria, mas também "no comércio e na agricultura, na administração pública, na própria ciência e no trabalho intelectual” (Revista do IDORT, n. 1, janeiro de 1932, p. 1).

${ }^{14}$ Além das publicações na revista do IDORT, publicou dois artigos na Revista do Arquivo Municipal: um sobre fonalidade e audição, partindo dos estudos do físico norte-americano Dayton Clarence Miller, em 1941; outro, décadas mais tarde, em 1980, dedicado à história dos ruídos em São Paulo.
} 
novembro de 1931, defende o uso da música - em especial aquelas em que o ritmo é sobressalente, como as marchas - em ambientes industriais onde atividades repetidas fossem realizadas pelas mãos de homens e mulheres. O ritmo seria capaz não apenas de melhorar a concentração, mas de estimular um gesto sincronizado e, consecutivamente, mais eficiente. ${ }^{15}$

Dezenas de outros trabalhos publicados na revista trataram de temas semelhantes, não apenas sobre música, mas sobre a importância do uso racional da luz ou das cores na criação de ambientes estimulantes, a sistematização de regimes culinários, ou a necessidade de ordenamento estético-racional dos espaços fabris, escritórios, escolas, e mesmo das ruas, ${ }^{16}$ muitos deles recheados de gráficos, quadros demonstrativos, contas, fórmulas, e slogans como "O quadro de controle diz tudo" (Revista do IDORT, n. 41, maio de 1935, p. 112), associando a racionalização do cotidiano a uma modernidade mais harmônica e estável. Estudos sobre as capacidades individuais também eram realizados através de testes de sensibilidade muscular, de movimentos, de capacidades visuais e de personalidade, estabelecendo modelos ideais de peso, estatura ou temperamento para cada função. ${ }^{17}$ Há uma proposição clara de união entre os universos das ciências sociais, da arte e da política com o mundo da ciência, da economia e do trabalho. São diversos os textos dedicados a firmar tais convergências. Um deles fecha o número 32 da revista (agosto de 1934). Intitulado "Ciências e Artes", trata essa proximidade entre os dois campos como um sintoma da vida moderna:

\footnotetext{
${ }^{15}$ Referindo-se ao exemplo de uma fábrica de charutos em Londres, o autor relata o que parece ser os primórdios da música-ambiente: "A firma fez instalar alto-falantes em todas as oficinas dedicadas a trabalhos de execução puramente maquinal. Um gramofone situado no escritório do apontador de diárias fornece a música. $\mathrm{O}$ apontador cuida do aparelho e procede a emissão, a certos intervalos. $\mathrm{O}$ gênero de música escolhido consiste em marchas, etc., isto é, oferece caráter estritamente rítmico. No correr do dia fazem-se ouvir quatro programas de meia hora cada um. Naturalmente é possível regular o ritmo da execução, o que leva o observador a verificar que as mãos das operárias se movem conforme o compasso da melodia executada. O rendimento aumentou e os erros desapareceram, por assim dizer" (Revista do IDORT, n. 7, julho de 1932, p. 21).

16 Ver, entre outros, "A racionalização das ruas" (n. 28, abril de 1934); "Inquérito sobre condições de iluminação nos lugares de trabalho de São Paulo" (n. 33, setembro de 1934); “A iluminação nas fábricas têxteis" (n. 18 e 21, junho e setembro de 1933); “A importância da boa iluminação" (n. 10-2, outubro, novembro e dezembro de 1932); "Luz: a melhor ferramenta do operário" (n. 17, maio de 1933); e "A racionalização da cozinha na Suécia” (n. 22, outubro de 1933).

${ }^{17}$ Ver "Teste de sensibilidade muscular" e "A capacidade visual na indústria" (n. 32, agosto de 1934); e “Estudos de movimento" (n. 33 e 34, setembro e outubro de 1934).
} 
A ciência já não é a organização da experiência humana; por sua vez, a arte já não é apenas o sofrimento que produz beleza (...). Foi a pedagogia, diante da necessidade de atrair a atenção do estudante, que primeiro misturou artes e ciências (...). O mesmo espírito que animou a pedagogia na realização dessa obra, anima hoje a publicidade. Os processos são muito parecidos e os fins muito aproximados. Enquanto uma utiliza-se da arte para divulgar conhecimentos científicos, outra recorre igualmente às expressões artísticas (...) para divulgar um conhecimento prático, de imediata utilidade para o cidadão. A pedagogia espalha a cultura, ilumina. A publicidade, beneficiando a cada indivíduo, incentiva a indústria e o comércio, faz as usinas trabalharem dia e noite e uma chusma de empregados do comércio e dos transportes ganharem o necessário para viver.

A penetração da ciência e da arte no cotidiano funcionava como forma de implementar modelos de otimização do tempo, do espaço e das capacidades individuais. Não apenas o operário, mas também o consumidor tornava-se alvo dessas novas ações que, unindo pedagogia e publicidade, buscavam formatar as práticas de consumo e de produção, otimizando-as ao máximo em função de ideais de lucro e expansão econômica inspirados no modelo norte-americano. Nesse cenário, as ciências sociais assumiam um importante papel. Não coincidentemente a Escola Livre de Sociologia e Política (ELSP) era fundada por um grupo de empresários em 1933, colocando o Estado de São Paulo, não mais como fonte de conflitos políticos, mas como estímulo a uma "revolução intelectual e científica" capaz de mudar as concepções econômicas e sociais dos brasileiros.

Ainda no ano de 1933 a Revista do IDORT publica um texto intitulado "A contribuição das ciências sociais para a reconstrução econômica" (n. 22, outubro de 1933), em que são associadas a pesquisa social e a nova ciência da gestão, as quais seriam as principais responsáveis pelo futuro da indústria. O Instituto recebeu em suas instalações, com certa frequência, professores da Universidade de São Paulo, proferindo conferências de interesse para o mundo empresarial. A música, nesse cenário, ocupou lugar significativo, fosse através de questões ligadas aos novos papéis da radiodifusão, ${ }^{18}$ fosse pela sua emergência como elemento educacional na escola. Sobre este último, Lellis Cardoso, que então lecionava no Conservatório Dramático e Musical de São Paulo,

\footnotetext{
${ }^{18}$ Ver, entre outros, o resumo da conferência do professor da USP Paul Vanorden Shaw proferida em 30 de agosto de 1937 sobre o papel do rádio na propaganda ("O rádio e a propaganda". In: Revista do IDORT, n. 70, outubro de 1937).
} 
caráter do indivíduo. Lellis Cardoso propõe uma análise científica da percepção musical de alunos desde as primeiras séries, mapeando suas capacidades e auxiliando um desenvolvimento adequado do corpo, do caráter, do temperamento, etc. O estudo tem continuidade no n. 47 da Revista (novembro de 1935), em que trata de questões fisiológicas, necessárias ao conhecimento mais claro dos "fenômenos sensoriais da psicologia da audição" (p. 244). Nesse artigo, o autor menciona a utilidade de aparelhos de medição das capacidades auditivas. Esses testes deveriam ser realizados nas escolas, aprimorando e expandindo o papel pedagógico da música. O orfeão escolar, idealizado por Heitor Villa-Lobos e que vinha progressivamente sendo implementado em todo o país, seria o ambiente ideal para o desenvolvimento de tal projeto pedagógico, que teria por fim a seleção voltada a fins educacionais e profissionais.

Por meio dessa seleção poderemos saber até onde chegam as possibilidades psicológicas do aluno e, consequentemente, sabermos se tal aluno promete algo na educação musical ou não; ou se é capaz de exercer certas profissões. Os alunos selecionados poderão ter a grafia de sua personalidade musical no perfil psicológico. Nesse perfil poderemos apreciar as capacidades musicais dos indivíduos como admiramos os aspectos de um rosto numa fotografia (REVISTA DO IDORT, n. 47, novembro de 1935, p.246).

Seguindo esta linha de estudos, a comunicação de Lellis Cardoso no I Congresso da Língua Nacional Cantada, intitulada “A fonofotografia e a fonética”, trata de apresentar a técnica, que consistia na tradução visual de impulsos sonoros através de aparelhos destinados ao "estudo científico do som e da fala, e também às medidas de capacidades que se englobam na voz" (CONGRESSO, 1938, p. 515). Cardoso toma por referência as pesquisas realizadas em universidades norte-americanas, em especial as obras de Carl E. Seashore, autor lido também por Mário de Andrade, ${ }^{19}$ e do físico Dayton Clarence Miller,

\footnotetext{
${ }^{19}$ Consta em sua biblioteca, hoje sob a tutela do Instituto de Estudos Brasileiros (IEB) da Universidade de São Paulo, um exemplar de The psychology of musical talent, de Carl Seashore, edição de 1919.
} 
que se dedicou ao estudo e à invenção de ferramentas necessárias à tradução do som para o horizonte da visualidade.

No texto apresentado por Lellis Cardoso, figura entre os objetivos principais a busca por uma "organização orquestral perfeita". ${ }^{20} \mathrm{O}$ aperfeiçoamento sonoro seria parte de um projeto educacional, exposto em outros textos do autor, ligado ao cenário do orfeão que se instalava ao longo do país naquele momento. A técnica da fonofotografia era apresentada como instrumento necessário a uma espécie de “orquestração subcutânea”, em que conta tanto a emissão quanto a recepção sonora. Seria útil, então, sob o ponto de vista psicotécnico, "para eliminar o barulho das fábricas, das ruas, que tanto prejudica o trabalhador e produz a fadiga" (CONGRESSO, 1938, p. 523); e, ainda, na sistematização da pronúncia definindo seu ritmo e acento. Este último quesito teria impacto fundamental sobre o corpo, transferindo-lhe os mesmos sinais de ordem e disciplina necessários à harmonização sonora de um coro.

O ritmo na palavra é o fluir dos movimentos subordinados a uma medição, ele governa os movimentos do corpo em ajustamento harmonioso, dá um sentimento de poder, de facilidade e de graça. Os movimentos rítmicos na prosa e verso tem uma base fisiológica, que se caracteriza pela alternação da tensão e afrouxamento das cordas vocais. Quando o som é produzido dá-se essa alternação na laringe (CONGRESSO, 1938, p. 526).

A escrita e a expressão poética seriam, nesse sentido, o reflexo de "um sincronismo dos movimentos do corpo com o ritmo da fala" (CONGRESSO, 1938, p. 527). Essa preocupação com as reações às experiências sonoras lidas através do corpo é central no texto de Lellis Cardoso. A recepção e os impulsos gerados pela audição de determinadas músicas, ruídos urbanos, acentos, alturas e timbres, eram questões que precisavam receber especial atenção. Conforme o autor,

\footnotetext{
20 "É comum encontrarmos discos fonográficos mal gravados, e isto é próprio, na maioria das vezes, dos fenômenos acústicos resultantes do som vocal com o som instrumental em face da velocidade do disco. Verificamos o mau efeito originado pela influência da massa coral sobre a instrumental e vice-versa; a má combinação de vogais e consoantes que resulta em ruído após a gravação do disco; a altura dos sons não adequada a certas vogais; palavras que uma vez entoadas são fracionadas pela fusão tonal" (CONGRESSO, 1938, p. 522).
} 


\begin{abstract}
"uma pessoa, com um esfigmógrafo [aparelho que traça a vibrações arteriais] adaptado na garganta ou em alguma outra parte do mecanismo da fala, está ouvindo uma música. O instrumento possui uma alavanca que uma vez bem ajustada, marcará o tempo musical que o paciente ouve. Ou seja, tal pessoa ao ouvir a música, sem perceber fica influenciada pelo ritmo, cujas marcações são feitas pelo esfigmógrafo. Os movimentos reais podem ser, por exemplo: marcar com o pé, com a cabeça, com o braço. É comum também marcar o tempo com os músculos da garganta e da língua ou pelos músculos maiores da coxa, do antebraço. Certas pessoas, para marcar o tempo, inclinam o corpo inteiramente, pois, tal atitude é uma forma extrema de ação coordenada de toda a musculatura do corpo na reação do tempo. Estes movimentos maiores, com os movimentos incipientes, são em geral, um tanto inconscientes, visto que podemos marcar o tempo com alguma parte do corpo, sem que o percebamos (CONGRESSO, 1938, p. 546-7).
\end{abstract}

O tempo torna-se ritmo da vida, que permite apreender no corpo, através do gesto, a paisagem sonora exterior. Mapear tais reações seria um passo fundamental na busca - explícita no projeto do canto orfeônico - por corpos disciplinados. Apesar de conservar os questionamentos que o ocupavam há cerca de dois anos nas publicações do IDORT, uma ênfase mais efetiva sobre o corpo toma forma no texto de Cardoso apresentado no Congresso. E a inserção das pesquisas de Dayton Clarence Miller é significativa, pois a ferramenta da fonofotografia parecia possibilitar a materialização de alguns problemas postos no contexto local.

2. O autor do segundo texto, Edgar Roquette-Pinto (1884-1954), era figura conhecida no meio político, cultural e científico nacional. ${ }^{21}$ Tendo vivido no Rio de Janeiro, e sendo mais ligado ao universo da ciência, Roquette-Pinto manteve-se a certa distância do Modernismo, embora tenha estabelecido relação com boa parte de suas figuras centrais. Correspondeu-se com muitas delas, especialmente Mário de Andrade, de quem recebeu vários questionamentos ligados à antropologia indígena durante o período em que dirigiu o Museu Nacional (1926-35). ${ }^{22}$ Foi nesse período, por volta de 1926, que o

\footnotetext{
${ }^{21}$ Médico legista por formação, atuou nas mais diversas áreas, transitando da ciência à antropologia, do romance à divulgação tecnológica. Ficou conhecido pelo seu papel fundamental na implantação e desenvolvimento da radiodifusão no país e por sua atuação no Instituto Nacional do Cinema Educativo (INCE), instituição que dirigiu desde a sua fundação em 1932 até 1947. Também é reconhecido por suas atividades como professor e divulgador da ciência no Brasil (ver LIMA e SÁ, 2008).

22 Parte dessa correspondência encontra-se no fundo Roquette-Pinto, junto ao acervo da Academia Brasileira de Letras. O acervo do Instituto de Estudos Brasileiros da USP também possui alguns registros da correspondência entre os dois intelectuais.
} 

tinha por meta oferecer uma alternativa à idealização romântica da natureza e do homem brasileiros: "tratava-se (...) de substituir a imagem de Peri, (...) de Alencar, pelo conhecimento científico dos indígenas e dos sertanejos brasileiros" (LIMA; SÁ, 2008, p. 72). Assim também com a música, que deveria deixar de ser apenas motivo nacional para tornar-se objeto de análise científica. Para tal tarefa - o registro de gestos e canções serviu-se amplamente da imagem - do desenho e da fotografia primeiro, e depois do cinema, além de maquinários estrambóticos. Manifestou, ao longo dos anos de trabalho, uma plena convicção de que o desenho e a imagem constituíam "um atencioso exercício de observação e conhecimento útil para a educação do brasileiro", que percebia como “impaciente e disciplinado” (LIMA; SÁ, 2008, p.272).

Além de anotar e fotografar, Roquette-Pinto também gravou e filmou a narração de lendas, o entoar das cantigas, o preparo da mandioca, as lides da tecelagem e da fiação. Lamentou inúmeras vezes o desprezo pelas formas de registro visual enquanto práticas de aprendizado e, como editor da Revista Nacional de Educação, publicada entre 1932 e 1934, organizou colunas regulares dedicadas a ensinar noções básicas de desenho e fotografia (LIMA; SÁ, 2008, p.272). A tradução visual de elementos da cultura popular constituía um problema para Roquette-Pinto desde 1910, quando viajou com Rondon ao norte do país. Como resultado, Rondônia, obra publicada em 1916, foi fartamente ilustrada, constituindo-se como um "documento de gestos, de seres humanos e objetos que o autor desejava fixar" (LIMA; SÁ, 2008, p. 272). A educação civilizadora dependia duplamente do universo da imagem: na condição de registro universal, sem as barreiras espaciais e culturais do livro; e na condição de exemplo, fornecendo a linha a ser seguida na busca por uma civilização forte porque homogênea.

A breve comunicação de Roquette-Pinto no Congresso de 1937 retoma parte dos estudos sobre fonética brasileira, iniciados em 1926 em seu laboratório no Museu Nacional. Inicialmente, a técnica usada consistia em tomar "numerosos gráficos de palavras e frases pronunciadas por indivíduos de várias regiões do país e alguns 
portugueses", registrando-os em papel enfumaçado. ${ }^{23}$ Os estudos foram retomados ao assumir a direção do Instituto Nacional de Cinema Educativo (INCE) em 1936 (cargo que exerceu até 1947), ao deparar-se com o problema da sonorização do filme "sub-standard" $(16 \mathrm{~mm})$, o que o animou a investigar possíveis formas de registro visual do som da voz. A técnica empregada nesse momento já é sensivelmente mais desenvolvida, permitindo ouvir, no aparelho de projeção, as palavras registradas no filme pelo oscilógrafo. Segundo Roquette-Pinto:

Tal circunstância, é claro, oferece garantias de rigorosa pesquisa. A minha aparelhagem compreende: microfone, amplificador, recorder de tração constante - (24 quadros por segundo), cerca de 11 metros de filme por minuto. Em vez de inscrever as vibrações do oscilógrafo na beira do filme, como se faz habitualmente nas fitas destinadas à exibição, resolvi aproveitar quase toda a largura do filme e inscrever integralmente as vibrações do raio luminoso. O oscilógrafo de que me sirvo é do tipo eletromagnético. A agulha de ferro macio, dentro da bobina que recebe as variações de corrente provenientes do microfone, acha-se no campo de um imã permanente. Na ponta da agulha, um pequeno espelho manda ao filme o raio luminoso recebido de uma lâmpada de filamento retilíneo. Na frente do filme, uma lente cilíndrica, que pelo próprio astigmatismo alonga ainda mais o feixe luminoso, dando na película as linhas bem visíveis. Como as linhas obtidas alcançam a beira do filme, as figuras resultantes da operação fornecem, no projetor, diante da célula fotoelétrica, os sons correspondentes. Pela minha técnica posso, destarte, ver bem as figuras das vibrações da voz e, sendo preciso, posso ouvir o que dizem os desenhos [grifo meu] (CONGRESSO, 1938, p. 697-8).

A técnica empregada por Roquette-Pinto consiste basicamente em registrar as vibrações sonoras que movimentam a agulha do oscilógrafo, ao mesmo tempo em que registra o som em si. Poderia ser utilizada, então, na identificação e unificação das pronúncias regionais, na harmonização e homogeneização de combinações sonoras, fossem elas instrumentais ou vocais, tudo através de uma leitura - cujos critérios aparentemente ainda não haviam sido definidos - da dimensão física do som a partir de sua tradução visual, a qual deveria fornecer a mais confiável tradução das expressões sensoriais e linguísticas do homem brasileiro.

\footnotetext{
${ }^{23} \mathrm{O}$ aparelho registrador era um oscilógrafo eletromagnético, provido de um estilete inscritor, vibrando de acordo com as vibrações recebidas de um microfone, através um amplificador de três válvulas b. f. 0 tempo era marcado por diapasão, em centésimos de segundo (Anais, 1937: 697-8).
} 
Roquette-Pinto, ao que tudo indica, manifestou interesse em dividir tais pesquisas com Mário de Andrade. Manuel Bandeira, em correspondência com este último, chama a atenção do amigo, provavelmente a pedido do próprio Roquette-Pinto, para a leitura do texto por ele enviado ao Congresso. Refere-se ao fato de o antropólogo ter telefonado diversas vezes a Mário em busca de tomar emprestado alguns discos (provavelmente aqueles produzidos no Projeto Arquivo da Palavra ${ }^{24}$ ) para tirar cópias pelo processo que havia criado (ANDRADE, 2000, p. 638-9). Não há resposta de Mário, tampouco qualquer comentário sobre a pesquisa de Roquette-Pinto ou de Lellys Cardoso. Sabe-se, enfim, que ambos foram convidados a participar do evento pelo Departamento de Cultura, o que denota, enfim, algum interesse sobre suas pesquisas.

Quase nada além dos textos publicados nos anais do Congresso, referente a essas pesquisas, foi preservado. No caso de Roquette-Pinto, nem no Museu Nacional, nem no INCE, nem no seu fundo junto à Academia Brasileira de Letras ( $A B L)$ constam registros sobre o assunto, o que dificulta uma verificação mais apurada. Há, de fato, uma enorme proximidade entre os métodos de Roquette-Pinto e Lellis Cardoso e as pesquisas do físico Dayton Clarence Miller, especialmente se levarmos em conta a associação, feita por todos os três, entre a tradução visual e a explicação científica. Gostaria de explorar estas questões mais a fundo.

\section{Fotografia, ciência, cotidiano}

O crescente espaço ocupado pelo cinema e pela fotografia nos primeiros anos do século XX criou a necessidade de conhecer e ver ausências diante dos olhos. Lugares longínquos através de filmes-documentários, formas de vida por meio de projeções microscópicas, o corpo humano através do raio-X, e assim por diante. Descobertas científicas e culturais que traziam para o mundo da visão aquilo que antes era só imaginável. É nesse cenário que se desenvolveram as pesquisas do físico norte-americano

\footnotetext{
${ }^{24}$ Projeto encabeçado por Mário e Oneyda Alvarenga, no qual eram gravadas vozes e acentos de regiões e grupos sociais diversos como parte da pesquisa folclórica empreendida pelo Departamento de Cultura e que integrará parte do acervo da Discoteca Pública.
} 
Dayton Clarence Miller (1866-1941). ${ }^{25}$ Matemático, físico e educador, vinculado à Case School of Applied Science em Cleveland, Ohio, durante boa parte de sua vida (1890-1936), Miller tornou-se conhecido primeiro por seu trabalho com raios-X. ${ }^{26}$ Colecionador de flautas e compositor em seu tempo livre, logo expandiu sua fascinação pelo universo sonoro à sua vida profissional. Chegou a desenhar flautas e realizar estudos acústicos de assessoria, contribuindo na arquitetura acústica de importantes construções nos Estados Unidos, incluindo aí o projeto acústico do Severance Hall em Cleveland. Também ministrou inúmeras palestras de demonstração do seu método de tradução do som através da fonofotografia dentro e fora dos Estados Unidos. ${ }^{27}$

O instrumento criado por Miller para tal tarefa, o phonodeik (1908) - do grego, mostrar o som -, possibilitava a visualização de ondas sonoras usando luzes refletidas num pequeno espelho conectado a um diafragma de mica - pedra utilizada também em gramofones -, o qual vibrava ao receber sons através de uma corneta, que poderia variar de tamanho e material. Miller produziu imagens de diversos sons: flautas e outros instrumentos de sopro, violinos, pianos, sinos, voz humana, armas de fogo. Partindo destas imagens, buscou formas de analisar e julgar a qualidade e as propriedades do som e dos instrumentos que o produziam.

\footnotetext{
${ }^{25}$ Os dados aqui apresentados são resultado de pesquisa realizada nos acervos do Rockfeller Institute (Department of Physics) da Case Western Reserve University (Cleveland - Ohio) e na Library of Congress (Washington - DC), financiada pela FAPESP. Agradeço ao Professor William Fickinger (CWRU) pelas dicas fundamentais, pelas longas conversas sobre a obra de Miller e pelo acesso irrestrito ao acervo do físico, por ele conservado.

${ }^{26}$ Fascinado com a descoberta de Konrad von Roentgen, criador da máquina de raio-X em 1895, Miller aprimorou a invenção e desenvolveu sua própria máquina, sendo o primeiro a produzir um raio-X completo do corpo humano, o seu próprio, no caso, em 1896.

27 Seu trabalho como físico deixou poucas razões para ser lembrado. Sua mais importante jornada, relacionada à existência do ether-drift, em busca de contestar as recentes descobertas do jovem Albert Einstein, foi fracassada. Talvez a grande marca deixada pelo físico tenha sido mesmo a preciosa coleção de flautas, com quase dois mil instrumentos e milhares de livros, documentos, fotografias e iconografias raras, e que hoje integra o acervo da Library of Congress em Washington, DC. Para maiores informações sobre D. C. Miller, ver FICKINGER, 2011.
} 


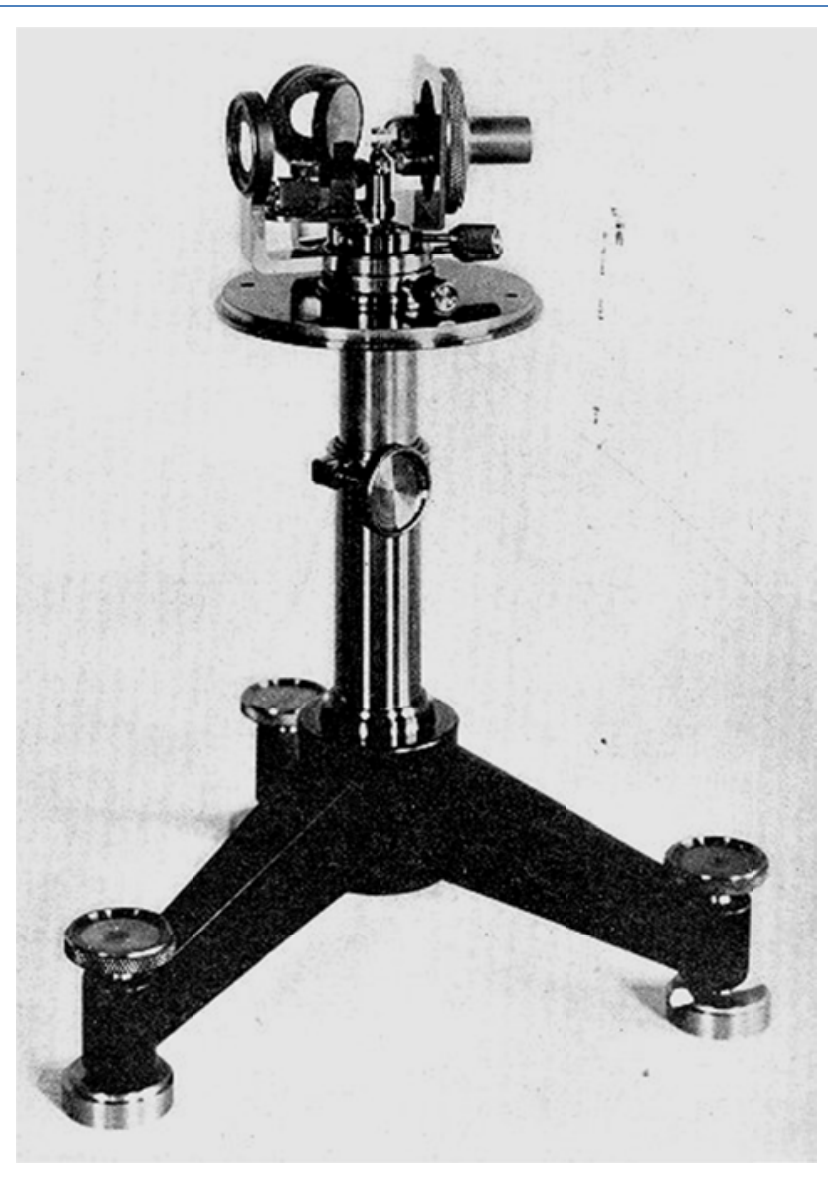

Phonodeik, instrumento criado por Dayton Clarence Miller, utilizado para "fotografar sons". O aparelho foi usado para capturar uma imensa variedade de sons em filme. Também foi utilizado durante a Primeira Guerra para medir duração e pressão das ondas emitidas por armas de diversos calibres, em busca de descobrir seus efeitos psicológicos sobre os soldados.
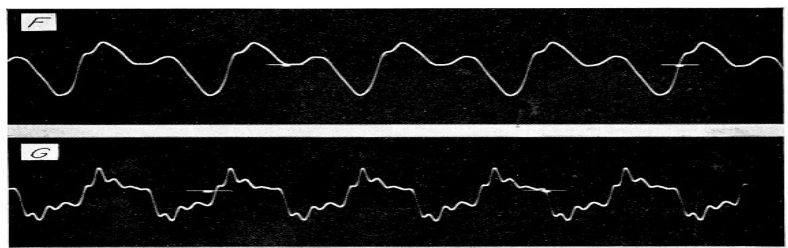

Phonodeik: Flauta, Clarinete, Oboé e Saxofone. A figura mostra as formas dias ondas de cada

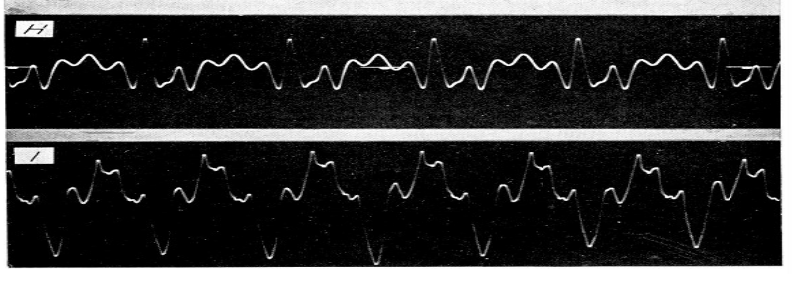
um dos instrumentos tocando a nota Dó (256 $\mathrm{Hz}$ ).

Já em 1909, menos de um ano após a invenção do phonodeik, jornais ao longo dos Estados Unidos noticiavam a descoberta de Miller e sugeriam usos inusitados para a máquina. O próprio Miller, hábil divulgador de seu trabalho, encontrava formas de atrair a atenção do público, dos jornais, e do meio científico, multiplicando assim as lectures realizadas em praticamente todos os estados norte-americanos, bem como no Canadá e em alguns países da Europa. Tais usos iam da aplicabilidade no fabrico de instrumentos e 
na engenharia acústica até ações de caráter totalmente popularesco. Um artigo intitulado "Kisses by mail" nos fornece um bom exemplo:

"Great strides should be made in osculautology within the next year. Not only can the canned kisses of loved ones be preserved, but by means of an instrument known as the phonodeik, the invention of Professor Dayton C. Miller, of Case School, which records sound waves with instantaneous photography, the sound of the kisses as well. By the same means the words inevitably accompanying a kiss: 'I love you', or 'You are the only girl (or boy) I ever loved', may be photographed and interred with the little dab of rouge - all that is mortal of a kiss. Then some night when you are fat and forty, or old and gray, you may put the record on the phonograph, and whilst your dimming eyes gaze at the love records of your life, hear the familiar cadences of some loved voice saying 'them [sic] fatal words' again. Pretty sentiment, what?" (The Cleveland Leader, $31 / 3 / 1912){ }^{28}$

Miller viajou durante anos realizando palestras de vulgarização e demonstração científica relacionadas ao phonodeik, com plateias que variavam entre 50 e 3000 ouvintes. Manchetes as mais variadas percorreram os principais periódicos norte-americanos anunciando a novidade e sugerindo a progressiva ausência de limites para as conquistas da ciência: "Can photograph sound, he says" (Evening Mail, NY, 25/5/1909), "Case professor flashes photos of human voice" (New York Sun, 26/5/1909), "Human voice is visible to eye" (Cleveland Plain Dealer, 5/1909), "Audiences sees pictures of applause" (Pittsburgh Gazette Times, 5/1/1912), "Sound waves make a big hit" (Stevens Institute of Technology, 22/2/1912). ${ }^{29}$

Apesar dos pouco significantes desdobramentos da invenção de Miller em termos científico-tecnológicos, o phonodeik encontrava espaço em meio a uma multidão sedenta

28 "Grandes avanços devem ser feitos na osculatologia [relativo ao verbo oscular, sinônimo de beijar] no próximo ano. Não só podem os beijos gravados de entes queridos serem preservados, mas por meio de um instrumento conhecido como phonodeik, invenção do Professor Dayton C. Miller, da Case School, que registra as ondas sonoras com a fotografia instantânea, o som dos beijos também. Da mesma forma, as palavras que inevitavelmente acompanham um beijo: "eu te amo" ou "Você é a única menina (ou menino) que amei", podem ser fotografadas e enterradas com um pequeno toque de rouge - tudo o que é mortal de um beijo. Então, uma noite, quando você já for um quarentão gordo, ou velho e grisalho, poderá colocar o disco no fonógrafo e, enquanto seus olhos cansados fitam os registros do amor de sua vida, ouvir as cadências familiares da voz da amada dizendo as palavras fatais novamente. Sentimento bonito, hein?". Tradução do autor.

${ }^{29} \mathrm{Na}$ hemeroteca do Rockfeller Institute (CWRU - Cleveland - Ohio), está preservada a coleção completa de reportagens sobre o tema organizada pelo próprio Miller. 
passa de mera obviedade, representou, um século atrás, uma revolução, criando um fascínio em torno das novas tecnologias e das infinitas possibilidades abertas por elas. 0 phonodeik dava vazão não apenas a este horizonte de expectativas. Trazia para o mesmo palco duas dimensões da expressão humana que ora se combinavam, ora se opunham: a sonora e a visual. A primeira, tida como representante da vida dos sentidos, dos instintos, conectada à mais pura expressão humana, a criação musical. A segunda, ferramenta de observação e esquadrinhamento da realidade, auxiliar da ciência e símbolo da razão. Trazer o universo sonoro para o mundo da visualidade significava desvendá-lo, inscrevê-lo numa situação de controle, de domínio. Sintoma de tais trocas é o texto publicado mais de duas décadas após o aparecimento do phonodeik, em 1931, pelo Evening Journal de Wilmington (Delaware, EUA), intitulado "Science of sound as great industry now". O editor abre o texto sugerindo: "The ears of the future probably will be as well trained as now the eyes are" [Os ouvidos do futuro provavelmente serão tão bem treinados quanto são nossos olhos agora]. Na sequência, quem argumenta é o especialista em assuntos acústicos William Braid White:

Fifteen years ago, acoustics, or the science of sound, was an inactive branch of physics. A few eminent workers like Dayton C. Miller were doing fine work in it, but neither they nor anyone else then could have suspected that their studies would soon become the center of a roaring activity. Yet this is just what has happened. The science of sound ought not perhaps to be too quiet; and at any rate it is today quite as noisy and as exciting as anyone could possibly desire. No branch of physical science is today of greater importance or is occupying the attention of a larger number of trained workers. What is the reason? Radio! Broadcasting and sound-picture making have become vast industries, calling for a great and increasing quantity of highly trained scientific instrument workers, and a vast amount of new apparatus, most of which was not even in existence fifteen years ago, and none of which had ever been seen outside the few acoustic laboratories then in existence (Evening Journal, $22 / 6 / 1931) .^{30}$

30 “Quinze anos atrás, a acústica, ou a ciência do som, era um ramo inativo da física. Alguns trabalhadores eminentes como Dayton C. Miller estavam fazendo um excelente trabalho nele, mas nem eles nem 
A preponderância repentina do universo sonoro seria resultado de duas causas essenciais: a proeminência do ouvido na era da radiodifusão, e a indústria cinematográfica. Ambas solicitavam uma compreensão mais detalhada do mundo sonoro, implicando sua tradução visual. A invasão sonora imposta por uma quantidade nova de informações que chegava através do ouvido - e não mais apenas através da visão - gerou novas necessidades, instigando questionamentos inéditos, no plano da tecnologia e da ciência em geral. Ao mesmo tempo em que novos mecanismos eram criados para melhorar a técnica do broadcasting ou a reprodução musical em filmes ou discos, estudos sistemáticos sobre o ruído eram promovidos nos EUA e na Europa com o fito de eliminar barulhos desnecessários através da medição da altura e dos efeitos possíveis sobre o homem. E novos mercados se abriam, conforme anunciavam os jornais da época. Tornava-se, então, fundamental conhecer as lógicas auditivas das massas e, mais do que isso, fornecer-Ihes moldes de consumo cultural. O desenvolvimento de novos meios para o estudo do som se dava em grande medida através de métodos ópticos e oscilográficos, ou seja, através de representações visuais de ondas sonoras. Em meio a este conjunto de transformações, Mr. White advertia:

Today our civilization is still far more eye-keen that [sic] is ear-keen. But sound is coming into her [sic] own, and the developments now taking place in the science of sound, acoustics, lead one to hope that the ears of the future will be as well trained as now the eyes are. If this is really comes [sic] about, as I think it will, the world will be a far more pleasant and harmonious place of residence twenty-five years from now than it now is (Evening Journal, 22/6/1931). ${ }^{31}$

qualquer outra pessoa, então, poderia ter suspeitado que seus estudos em breve se tornariam o centro de uma atividade em alta. No entanto, é isso que aconteceu. A ciência do som não pode ser muito silenciosa; e hoje é tão barulhenta e emocionante quanto qualquer um poderia desejar. Nenhum ramo da física hoje tem maior importância ou está ocupando a atenção de um número maior de pesquisadores treinados. Qual é a razão? Rádio! A radiodifusão e a fotografia do som tornaram-se grandes indústrias, apelando a uma grande e crescente quantidade de operadores de instrumentos científicos altamente treinados, e uma grande quantidade de novos aparelhos, a maioria dos quais ainda não existia quinze anos atrás, e nenhum dos quais já havia sido visto fora dos poucos laboratórios acústicos então existentes". Tradução do autor.

31 "Hoje nossa civilização ainda muito mais é visual do que auditiva. Mas o som está ganhando território próprio, e os desenvolvimentos ocorrendo agora na ciência do som, a acústica, despertam a esperança de que os ouvidos do futuro serão tão bem treinados como agora são os olhos. Se isso for realmente acontecer, como eu acho que vai, o mundo será um lugar muito mais agradável e harmonioso para viver daqui a vinte e cinco anos do que é agora". Tradução do autor. 
A ideia de uma civilização dirigida não apenas pelo sentido da visão, mas também pela audição demandava uma associação entre os dois sentidos, sendo o primeiro modelar no processo evolutivo do segundo. A visão seria, portanto, a base na trajetória de esquadrinhamento do mundo dos sentidos, seguindo a tradição oculocentrista ocidental, na qual a capacidade de ver se confunde com a cognição (ver JENKS, 1995. p.1; MCLUHAN, 2005). Note-se que há um paradoxo entre a relação visual/sonoro tal qual proposta desde fins do século XVIII, perpetuando-se do romantismo ao Modernismo, no qual a música, pela sua antiobjetividade, deveria ser modelo para as artes visuais e narrativas de forma geral; e o visual/sonoro tal qual descrito acima, em que, ao contrário, a visualidade é que deveria atuar como modelo no desenvolvimento da vida sensorial representada pelo universo sonoro.

A conexão entre o mundo moderno, tecnológico, e a expansão dos horizontes de consumo formatava um novo olhar sobre o corpo. Embora percebido na chave da sensorialidade, como consumidor de estímulos sensoriais, o corpo representava também a possibilidade de otimização das forças engajadas na produção e de controle e previsão do gesto consumidor. O uso das pesquisas de Miller foi diverso, conforme procurei apontar brevemente. Contudo, talvez tenha sido a apropriação do seu método pelo campo da antropologia, mais especificamente o da etnologia, a principal responsável pelo seu uso no I Congresso da Língua Nacional Cantada. Nos Estados Unidos, o Bureau of American Ethnology ${ }^{32}$ vinha promovendo estudos arqueológicos e etnológicos ao longo do país, sendo a música indígena alvo privilegiado de tais pesquisas. Em 1920, a etnógrafa e etnomusicóloga Frances Densmore utiliza o método da fonofotografia (tone photographs) criado por Miller. Constam em seu livro sobre a música dos Ute (DENSMORE, 1922), etnia que povoava o atual estado de Utah nos Estados Unidos, gráficos e análises obtidos a partir do phonodeik. Mário de Andrade possuía algumas obras da antropóloga norte-americana. E muito provavelmente Roquette-Pinto e Cardoso também tiveram contato com o seu trabalho, fato que pode ter inspirado a realização das referidas pesquisas. O interesse pela fonofotografia no Brasil parece ter ficado restrito ao

\footnotetext{
32 Criado em 1879 com o propósito de transferir arquivos e gravações relacionados aos indígenas norteamericanos do Departamento Interior para a Smithsonian Institution.
} 
Lellis Cardoso, este último é citado. Segundo Seashore, Cardoso estaria se apropriando de problemas e conceitos já superados em sua obra: "It is astonishing how enthusiastically he treats a number of things which are decidedly out of date. I refer, of course, to my part" [É surpreendente o quão entusiasticamente ele aborda algumas questões que estão decididamente desatualizadas. Eu me refiro, é claro, à minha parte] (Carta de C. Seashore a D. C. Miller, 29/10/1938, Library of Congress).

Provavelmente nem Seashore nem Miller tinham conhecimento das discussões e projetos que moviam intelectuais, artistas e cientistas por aqui. E não há notícias de usos da técnica fonofotográfica semelhantes aos propostos no Congresso por Lellis Cardoso ou por Roquette-Pinto em território norte-americano. A leitura de suas comunicações, unida a uma visão geral do contexto em que estavam inseridas, e ao conhecimento de algumas das referências utilizadas, deixa entrever os contornos de um projeto voltado ao controle e disciplinarização das culturas populares. Instrumentos como o phonodeik ajudariam a pôr em prática tópicos como a unificação dos acentos e da língua, a otimização produtiva no setor industrial, o aprimoramento da cultura musical, e a seleção de elementos ideais à constituição de uma identidade sonora nacional.

Diferente do caso norte-americano, em que a pesquisa da música indígena não se conectava de forma visceral ao problema da identidade nacional, seguindo o molde europeu de interesse pela "alteridade" - a busca pelo exótico -, o trabalho etnográfico no Brasil misturava-se às políticas culturais empreendidas pela intelectualidade e pelo Estado. O caso dos textos apresentados por Roquette-Pinto e Lellis Cardoso no Congresso, é indício de uma forte presença da matriz sonora na cultura brasileira conforme professaram Gilberto Freyre, Mário de Andrade, entre outros -, assumindo a sensorialidade como um problema da ciência moderna, de interesse não apenas etnográfico, mas sobretudo político-cultural. Tais estudos deveriam servir como instrumentos na elaboração de medidas de controle e educação do corpo e dos sentidos, redutos da capacidade expressiva do povo. Reagem, de certo modo, à autonomia 
1916), ou mesmo das impressões corporais da experiência musical (Seashore), são ponto de partida para a análise das capacidades e limitações sensoriais e perceptivas. A proeminência da música na elaboração da identidade brasileira, entendida dentro de uma lógica sensorialista de civilização tropical, deveria ser dominada, mapeada e unificada, fornecendo os contornos de uma nação imponente, porque unificada em suas entranhas.

\section{Política dos sentidos}

Inicialmente tomado como instrumento de atualização estética, o mundo sonoro passa a ser também alvo de políticas culturais de intento homogeneizador. Este processo implicava não mais o aprendizado da visão com referências de outros sentidos, sobretudo da audição - tal qual professaram artistas modernos como Kandinsky (ARNALDO, 2003), Klee (DÜCHTING, 2004), Matisse (HUGHES, 1991; MATISSE, 1992), entre outros -, mas a síntese, ou melhor, a redução destes materiais sensoriais ao domínio do visual. De qualquer maneira, as experiências de Miller e Seashore, de Roquette-Pinto e Lellis Cardoso extrapolam o âmbito da alegoria, no qual estavam restritas algumas das experiências artísticas do modernismo, levando ao universo da ação os diálogos entre o visual e o sonoro.

O problema da integração entre os sentidos ou da renovação da visualidade pictórica deve ser entendido, nesse contexto, como ferramenta política. Capaz de oferecer respostas aos dilemas do progresso e aos questionamentos identitários conectados à mestiçagem étnica e cultural, serviu a propósitos distintos, firmando hierarquias sensoriais plurais, adaptadas às necessidades do lugar e do momento. Para dar conta de tais significados, o termo intersensorialidade é, sem dúvida, mais apropriado do que o conceito de sinestesia, pois não implica, conforme sugere David Howes, um estado de harmonia ou igualdade - seja ela sensorial ou social, comportando as hierarquias presentes em cada contexto cultural (HOWES, 2005, p. 10). 
Embora seja difícil identificar a existência de qualquer repercussão direta das pesquisas de Roquette-Pinto e Cardoso na produção visual ou literária da época, é possível sugerir certa afinidade entre a sua origem e o câmbio no tratamento do corpo e nas noções de arquitetura e equilíbrio plásticos na obra de alguns pintores ativos antes, durante e depois do Estado Novo. ${ }^{33}$ Estas pesquisas tiveram, de fato, um impacto restrito. Pouco comentadas e, ao que tudo indica, abandonadas após o Congresso de 1937, não tiveram qualquer implicação prática ou científica de grandes proporções. Tornam-se relevantes, entretanto, à medida que indicam o significativo espaço ocupado por uma “cultura sensorialista” em meio às políticas - estatais ou não - voltadas à realização de um projeto identitário. O termo "sensorialismo" emerge como ideologia pautada pelo recurso aos sentidos, forjando hierarquias sensoriais interessantes à sua plena realização (TÉO, 2012). Nesse cenário, o sonoro e o visual aparecem como categorias salientes no delineamento das práticas e projetos direcionados ao modelamento da cultura e dos homens e mulheres brasileiros no período em questão. Nesse sentido, fontes que contemplem essas duas dimensões podem oferecer respostas singulares a problemas que marcaram a atuação de artistas, intelectuais e políticos naquele momento, sobretudo no que diz respeito à constituição de uma identidade - estética, cultural e política nacional.

Discutir o lugar do visual nas políticas culturais do Brasil por volta de 1930 a partir destes dois trabalhos aparentemente pouco relevantes ajuda a expor algumas das possíveis implicações práticas das tais "teorias do Brasil”. O Congresso de 1937 - e o entorno que lhe deu forma - pode ser visto como um símbolo de superação, pelo Modernismo da década de 1930, do paradoxo, apontado por Mônica Pimenta Velloso, entre o moderno-ciência e o moderno-estética, que marca a visão da intelectualidade brasileira desde fins do Império acerca da modernidade. Diferenças essas que impulsionavam disputas entre profissionais da ciência e homens de letras. Os primeiros se autodefiniam como "lutadores, defensores do progresso científico da nação", ao mesmo

\footnotetext{
33 O caso de Portinari é exemplar nesse sentido. Uma análise mais detalhada de algumas de suas obras (sobretudo as encomendas institucionais), aponta o paradoxo criado entre suas impressões e experiências da cultura e da música brasileiras e as adaptações necessárias à sua constituição profissional, atrelada, nesse momento, às encomendas estatais (TÉO, 2015).
} 

imediatistas e utilitários" dos primeiros (VELLOSO, 1996, p. 38). Esse dilema se dissolve para dar forma a um acordo político que engloba arte e ciência em prol da dita construção nacional. A atuação de Gustavo Capanema nos anos subsequentes tenta justamente reforçar esse acordo. As discussões em torno do (não) monumento ao homem brasileiro no Palácio Capanema, por exemplo, são claros indícios do interesse do ministro e do Estado em articular justificativas científicas e monumentos estéticos na tarefa anunciada pelo seu ministério: formar o homem brasileiro (PINTO JÚNIOR, 2007).

$$
* * *
$$

A ênfase dada aos sentidos da visão e da audição neste artigo não foi construída, como o leitor já deve ter percebido, por uma exaustiva análise de documentos visuais e sonoros. É fruto, por outro lado, de uma tentativa de "cartografá-los", localizando seus territórios, suas trajetórias, sua mobilidade e dinâmica dentro do grande mapa políticosensorial do período e do espaço abordados. Interessam menos, nesse sentido, os debates sobre a ontologia da fotografia ou do som, centrados no vínculo que um documento mantém com seu referente. Interessa, por outro lado, o uso prático destes vestígios, capaz de provocar deslocamentos (espaciais e de significado) em seu referente e, sobretudo, dar indícios importantes das relações estabelecidas entre os sentidos, e entre o sensorium e o mundo da política. Há que se considerar, portanto, o papel da fotografia na "remodelação de todo um território no qual sinais e imagens, efetivamente apartados de um referente, circulam e proliferam" (CRARY, 1990, p. 13), criando modos de ver e expectativas de registro visual que excedem, por vezes, o próprio universo da visualidade, como mostra a recepção dos experimentos de Dayton Clarence Miller por exemplo.

A pretensa capacidade de reproduzir fragmentos do mundo vivido através da fotografia foi, ao longo do século passado, e continua sendo, de forma significativamente ampliada, uma das principais plataformas sob as quais nos relacionamos, enquanto observadores, com o passado. Registramos o presente tornando-se passado de forma a 
e inúmeras formas de posicionar o sentido da visão nos mapas da percepção do mundo. Procurei explorar neste artigo uma faceta bastante específica, que traz à tona uma concepção também particular sobre a função e a potencialidade do visual no campo da política. Nesse cenário, o suporte fotográfico é parte de uma história dos sentidos, ajudando a formar, se não novas hierarquias sensoriais, pelo menos novas formas e estruturas de relacionamento entre os sentidos. Nesta perspectiva, as imagens do som, pouco atraentes em termos visuais, conquistam grande importância, pois são sintomas relevantes desse universo dinâmico que constitui as relações intersensoriais.

\section{Referências}

ANDRADE, Mário de. Correspondência: Mário de Andrade \& Manuel Bandeira. São Paulo: Edusp; IEB; USP, 2000.

ANDRADE, Mário de. Portinari, amico mio: cartas de Mário de Andrade a Cândido Portinari. Campinas: Mercado de Letras; Autores Associados; Projeto Portinari, 1995.

ARNALDO, Javier. Analogías musicales: Kandinsky y sus contemporáneos. Madrid: Fundação Museo Thyssen-Bornemisza, 2003.

BATISTA, Marta Rossetti. Coleção Mário de Andrade: religião e magia, música e dança, cotidiano. São Paulo: EDUSP; Imprensa Oficial, 2004.

CALABRE, Lia. A era do rádio. Rio de Janeiro: Jorge Zahar, 2004.

CHARNEY, Leo; SCHWARTZ, Vanessa. O cinema e a invenção da vida moderna. São Paulo: Cosac Naify, 2004.

CHATWIN, Bruce. O rastro dos cantos. São Paulo: Companhia das Letras, 1996.

CONGRESSO DA LÍNGUA NACIONAL CANTADA, 1, São Paulo, 1938. Anais... São Paulo: Departamento de Cultura, 1938. 
CRARY, Jonathan. Techniques of the observer: on vision and modernity in nineteenth century. Cambridge: MIT Press, 1990.

DENSMORE, Frances. Northern ute music. Washington: Bureau of American Ethnology, 1922.

DÜCHTING, Hago. Paul Klee: painting music. Munich: Prestel, 2004.

FICKINGER, William. Miller's waves: an informal scientific biography. Cleveland: Case Western Reserve University, 2011.

HOWES, David. Empire of the senses: the sensual culture reader. New York: Oxford; BERG, 2005.

HUGHES, Robert. The shock of the new: art and the century of change. London: Thames \& Hudson, 1991.

JENKS, Chris. The centrality of the eye in Western culture: an introduction. In: Visual culture. London: Routledge, 1995.

LIMA, Nísia Trindade; SÁ, Dominichi Miranda de. Antropologia brasiliana: ciência e educação na obra de Edgard Roquette-Pinto. BH; RJ: UFMG; Fiocruz, 2008.

MATISSE, Henri. Jazz. Nova York: George Braziller, 1992.

MCLUHAN, Herbert Marshall. Inside de five sense sensorium. In: HOWES, David. Empire of the senses: the sensual culture reader. New York: Oxford; BERG, 2005, p. 43-52.

MILLER, Dayton C. The science of musical sounds. New York: Macmillan Company, 1916.

NOGUEIRA, Antônio Gilberto Ramos. Por um inventário dos sentidos: Mário de Andrade e a concepção de patrimônio e inventário. São Paulo: HUCITEC; FAPESP, 2005.

PARANHOS, Adalberto. Vozes dissonantes sob um regime de ordem-unida (música e trabalho no 'Estado Novo'). ArtCultura, Uberlândia: UFU, v. 4, n. 4., junho de 2002.

PEREIRA, Maria Elisa. Lundu do escritor difícil: canto nacional e fala brasileira na obra de Mário de Andrade. São Paulo: Editora UNESP, 2006.

PINTO JÚNIOR, Rafael Alves. Imagem e cidade: memória do (não) monumento ao homem brasileiro no Palácio Capanema. Revista de História Social, n. 13. Campinas, 2007, p. 209-19. 
REVISTA DO IDORT. São Paulo: IDORT, 1932-1945 (n. 1, 7, 10-2, 17-8, 21-2, 28, 32-4, 43, 47, 70).

ROMERO, Sílvio. Estudos sobre a poesia popular do Brasil. São Paulo: Vozes, 1977.

SEASHORE, Carl E. The psychology of musical talent. New York: Silver, Burdett \& Company, 1919.

SERPA, Élio. Congresso da Língua Nacional Cantada de 1937: a insensatez maravilhosa da militarização das vogais. Nacionalismo, raça e língua. Diálogos Latino-americanos, Dinamarca: Centro de Estudos Latino-Americanos (CLAS), n.3. 2000.

SILVA, Flávio (Org.). Camargo Guarnieri: o tempo e a obra. São Paulo: Imprensa Oficial, 2001.

TÉO, Marcelo. A vitrola nostálgica: música e constituição cultural em Florianópolis (décadas de 1930 e 1940). Florianópolis: Letras Contemporâneas, 2007.

TÉO, Marcelo. Da primeira missa à primeira aula de música: Portinari, Capanema e os debates em torno dos marcos fundadores do Brasil moderno. In: VOJNIAK, Fernando (Org.). História e linguagens: memória e política. Jundiaí: Paco Editorial, 2015.

TÉO, Marcelo. 0 tocador pelo pincel: o sonoro, o visual e a sensorialidade do modernismo à Era Vargas. 2012, 378f. Tese (Doutorado em História) - Universidade de São Paulo, Faculdade de Filosofia, Letras e Ciências Humanas FFLCH, São Paulo, 2012.

TURIN, Rodrigo. Tempos cruzados: escrita etnográfica e tempo histórico no Brasil oitocentista. 2009, 242f. Tese (doutorado em História) - Universidade Federal Fluminense, Rio de Janeiro 2009.

VELLOSO, Monica Pimenta. Modernismo no Rio de Janeiro: turunas e quixotes. Rio de Janeiro: Fundação Getúlio Vargas, 1996. 
Recebido em 07/03/2016 Aprovado em 29/04/2016

Universidade do Estado de Santa Catarina - UDESC Programa de Pós-Graduação em História - PPGH

Revista Tempo e Argumento Volume 08 - Número 17 - Ano 2016 tempoeargumento@gmail.com 